\title{
THE IDEOLOGICAL MATRIX OF SCIENCE: NATURAL SELECTION AND IMMUNITY AS CASE STUDIES
}

\author{
Agustin Ostachuk
}

\begin{abstract}
The modern concept of ideology was established by the liberal politician and philosopher Destutt de Tracy, with the objective of creating an all-embracing and general science of ideas, which followed the sensualist and empiricist trend initiated by Locke. He also built his political economy upon the liberal concepts from Adam Smith and Thomas Malthus. The Malthusian concept of struggle for existence wrongly assumed that population grew faster than the means of existence. This "natural" law contained implicitly the idea that the poor and least gifted would not survive. This idea led to the progressive development of the concept of natural selection, whose definitive version was given by Darwin. Mechnikov took both these concepts and conceived immunity as a struggle between a host and its invader, the so-called phagocytosis theory. This theory created the necessity to possess mechanisms to discriminate between the own and the foreign, and led to the conception of the immune self. These concepts were not developed from ideas coming from perceptions or sensations, but from ideas coming from their values: individual interest, inevitable inequality, property, utility and profit. Values are ideals that constitute an ideological matrix that exerts a numinous activity and inspire us and impulse us towards certain directions.
\end{abstract}

KEYWORDS: Ideology; Natural selection; Immunity; Self; Values; Ideological matrix 


\section{IDEOLOGY AS A SGIENGE OF IDEAS}

\section{Ideologists, ideologues or both?}

Ideology has currently a negative and pejorative connotation, especially in science. It is placed next to vice, bad habit and moral corruption, and as such, being incompatible with a pure and aseptic activity as science. However, and as weird and ironic it could sound today, in its origin Ideology was intended to be a strictly scientific discipline. The negative connotation that the term acquired was a result of its application and usage in the French political arena, during the times of Napoleon Bonaparte.

The "ideologists" [idéologues] were an intellectual group composed of many renowned and celebrated scientists. This group consisted of many members of the Institut de France, founded in I795, such as Antoine Destutt de Tracy (philosopher), Pierre Cabanis (physician), Constantin-François de Chassebœuf (Volney, historian), Jean-Baptiste Say (economist), among others. They were the forerunners of positivism, a philosophical theory and worldview that it was going to be synthetized by Auguste Comte in the r 830 s.

Antoine Destutt de Tracy (I754-I836) published from I80i to I8I5 his work entitled Eléments d'Idéologie, where he tried to develop a "science of ideas". Destutt de Tracy's major philosophical influences were John Locke (I632-I704) and Étienne Bonnot de Condillac (I714-1780), so he attached himself to an empiricist tradition which can be traced up to Francis Bacon (I56I-I626). The point of departure of Destutt de Tracy was the debunking and overthrow of metaphysics as "first philosophy" and its replacement by logics. The science of human understanding should not be "a hypothetical science", nor a science "based on frivolous assumptions", but a science that started "from a wellcertified and well-proven fact; the perceptions of our sensitivity, that is, our sensations", because they were "the source and origin of all our ideas" (Destutt de Tracy I796, p. 289). The underlying hypothesis was the sensualist conviction, adopted from Locke and Condillac, that sensory perceptions were the only source of our ideas.

In this context, Destutt de Tracy proposed the creation of a new science which he called Ideology. He considered Ideology as a natural science (a part of Zoology) and devoted to study the means of knowing and teach us to judge and 
reason. The first sketch of this new science was presented and published as an article in Mémoires de l'Institut National des Sciences et Arts: Sciences Morales et Politiques, in I796: "I would much prefer, then, to adopt the term ideology, or science of ideas. It is very appropriate, for it supposes nothing doubtful or unknown; it does not remind us of any idea of cause. Its meaning is very clear to everybody [...] for everyone knows what it is meant by an idea" (Destutt de Tracy I796, p. 324). The basic element of this system was the idea. Ideas were the elements and forms of perception, therefore, they were the basic elements of knowledge: "our perceptions or our ideas (I will always make these two words absolutely synonymous) are the things that we feel" (Destutt de Tracy I8I7a, p. 25). In this manner, ideas were received directly from the senses, that is, sensations were themselves ideas. Consequently, "thinking [was] feeling" (Destutt de Tracy I8ı7a, p. 25) and to think was simply to have perceptions. Sensitivity, memory, judgment and will, were all different kinds of feeling: the faculty of feeling sensations, the faculty of feeling recollections, the faculty of feeling relations/connections, and the faculty of feeling desires, respectively. On the other hand, complex ideas were built from combinations, relations and connections among simple ideas. In consequence, the modern usage of the term ideology was born as an empiricist science of ideas rooted in the sensualist theories of Locke and Condillac.

In his ascending career with successful military campaigns, Napoleon sought the support of the ideologists and he became a member of the Institut in I797. The ideologists first supported Napoleon and they promoted his accession to power in I799, when he organized a coup and became First Consul of the Republic (Lichtheim i964). Many members of the group (including Destutt de Tracy) were elected by Napoleon as senators of the new government. As Napoleon's power increased and concentrated, the relation between them deteriorated drastically and turned hostile. The first discord was Napoleon's reconciliation with the Catholic Church, the Concordat of I8or, which was opposed to the secular views of the ideologists, and the ideas from the Revolution which they defended. Afterwards, in I803, Napoleon dissolved the "Second Class" of the Institut, the section devoted to Moral and Political Sciences (and the one to which Destutt de Tracy belonged as associate member). Napoleon saw ideologists' political and economic liberalism as a 
threat to his protectionist economy and centralist politics. Consequently, he condemned ideology as "shadowy metaphysics" and the ideologists as "disguised materialists" (Kennedy I979), and the use of the term "ideology" with a pejorative and derogatory connotation began. The ideologists were denounced as ideologues against the Republic. These allegations were not unfounded, the ideologists participated in the Malet conspiracies and coup attempts of 1808 and I8I2.

The ideologists, therefore, were not mere scientists, they were also accomplished politicians and participated actively in the political scene of their time. In spite of the apparent neutrality and empirism in his scientific approach, Destutt de Tracy's refoundational work on ideology was not intended to be only a treatise on logics and linguistics. The fourth and fifth parts, published as the fourth volume of the series, was entitled Traité de la volonté et des ses effets ( $18 \mathrm{I}_{5}$ ) and versed on economics and moral ${ }^{1}$. Following his general approach, will arised from perception, and with will all the well-known ideas from liberal economy, almost with a necessity of a natural law. For example, the idea of property was the inevitable consequence of the existence of the idea of personality, which, in turn, derived necessarily from will.

\section{Economic ideas as natural lawes}

There was an inevitable consequence of establishing, as the point of departure, ideas as complex relations of perceptions: "man alone makes exchanges" (Destutt de Tracy i8ı bb, p. I4) 2. Man was an animal of exchanges, a trading animal, and therefore "society [was] purely and solely a continual series of

\footnotetext{
I This volume was translated into English, edited by Thomas Jefferson, and published in I8I7 with the title "A treatise on political economy" (Destutt de Tracy I8I7b). This translation is used in this work for citation purposes. Citations were compared with the original version to check accuracy.

${ }^{2}$ He was intending to quote a phrase from Adam Smith, whose exact terms were the following: "This division of labour, from which so many advantages are derived, is not originally the effect of any human wisdom, which foresees and intends that general opulence to which it gives occasion. It is the necessary, though very slow and gradual consequence of a certain propensity in human nature which has in view no such extensive utility; the propensity to truck, barter, and exchange one thing for another. Whether this propensity be one of those original principles in human nature of which no further account can be given; or whether, as seems more probable, it be the necessary consequence of the faculties of reason and speech, it belongs not to our present subject to inquire. It is common to all men, and to be found in no other race of animals, which seem to know neither this nor any other species of contracts" (Smith I79I, vol. I, p. I9).
} 
exchanges" (Destutt de Tracy i8ı 7 b, p. 6). With those premises and consequent deductions, it was also natural that wealth came from production ${ }^{3}$, and that value was to be defined as a measure of utility ${ }^{4}$. Now, if the means of production determined the means of existence, then the problem was distribution. And according to Destutt de Tracy, these means were insufficient and unequal distribution was inevitable as it was natural: "These resources, these riches, so insufficient for happiness, are also very unequally divided amongst us; and this is inevitable. We have seen that property exists in nature: for it is impossible that everyone should not be the proprietor of his individuality and of his faculties. The inequality in these is not less: for it is impossible that all individuals should be alike, and have the same degree of force, intelligence and happiness. This natural inequality is extended and manifested in proportion as our means are developed and diversified" (Destutt de Tracy i8I7b, p. i I I). The last step of this apparently inevitable situation was provided by the work of Thomas Malthus: "M. Malthus goes much further still. He is, at least as far as I am acquainted, of all the authors who have written on population, the one who has treated the subject the most profoundly, and has developed all its consequences. His work, singularly remarkable, should be regarded as the last state of science on this important object, and he leaves almost nothing to be desired. M. Malthus does not limit himself to prove, that though population is arrested at different degrees in different countries, and according to different circumstances, it is always and everywhere as great as it can be, having regard to the means of existence. He shows that always in civilised nations it is too great for the happiness of man; because that men, and above all the poor, who everywhere constitute the great number, urged by the stimulus so imperious to reproduction, always multiply imprudently and without foresight; and plunge themselves into inevitable misery by a multiplication of the men, who demand occupation, and to whom none can be given" (Destutt de Tracy i8izb, p. I28). Therefore, inequality was a consequence of differential physical and mental capacity, and the increase of the means of production intensified that inherent

\footnotetext{
3 "To be rich is to possess these goods; to be poor is to be without them" (Destutt de Tracy I8I 7 b, p. XIII). 4 "Utility [...] constitutes the value of whatsoever we call our riches" (Destutt de Tracy i8izb, p. 25). Destutt de Tracy recognized labour as accounting for the value of a product, but ultimately for him to produce "is to give things an utility which they had not. Whatever be our labour, if no utility results from it it is unfruitful. If any results it is productive" (Destutt de Tracy I8I7b, p. 20).
} 
inequality. Moreover, population tended to grow beyond its means of existence, and misery inevitably increased among the poor.

Thomas Malthus (I766-I834) had proposed a few years earlier (I798) that, as population increased faster (in geometrical ratio) than the means of existence (arithmetical ratio), a series of checks on populations existed which secured a certain balance between them ${ }^{5}$. These checks were numerous, but all "may be fairly resolved into misery and vice" (Malthus I798, p. I0o). The positive checks to population, that is, "the check that represses an increase which is already begun" (Malthus I798, p. 7I), did not exert their action evenly in all social strata: "the misery that checks population falls chiefly, as it always must do, upon that part whose condition is lowest in the scale of society" (Malthus I798, p. $4 \mathrm{I})$. For Malthus, misery was an inevitable law of nature and, therefore, it could never be eradicated or eliminated: "Is it not a degree of misery, the necessary and inevitable result of the laws of nature, which human institutions, so far from aggravating, have tended considerably to mitigate, though they never can remove" (Malthus I798, p. I94). As "to prevent the recurrence of misery, is, alas! beyond the power of man. In the vain endeavour to attain what in the nature of things is impossible" (Malthus I798, p. 98), Malthus was a fervent proponent of the elimination of the Poor-Laws, created to ameliorate the economic situation of the lower classes of the society. He believed that cooperation was prejudicial and every man should stand for himself. His solution for improving the condition of the poor was that they assume their own duties: "The happiness of the whole is to be the result of the happiness of individuals, and to begin first with them. No cooperation is required. Every step tells. He who performs his duty faithfully will reap the full fruits of it, whatever may be the number of others who fail. This duty is intelligible to the humblest capacity. It is merely, that he is not to bring beings into the world, for whom he cannot find the means of support. When once this subject is cleared from the obscurity thrown over it by parochial laws and private benevolence, every man must feel the strongest conviction of such an obligation. If he cannot support his children, they must starve; and if he marry in the face of a fair

\footnotetext{
${ }^{5}$ Malthus' essay from I798 was a response, as the full title indicated, to Godwin and Condorcet's belief in the indefinite progress of humanity. His principle of population was a concept devised to set a limit to that progress, establishing a natural context of scarcity.
} 
probability that he shall not be able to support his children, he is guilty of all the evils, which he thus brings upon himself, his wife and his offspring" (Malthus I826, vol. 2, p. 285).

\section{NATURAL SELEGTION OR THE STRUGGLE FOR EXISTENCE IN NATURE}

\section{Darwin's education and the voyage in the Beagle}

The HMS Beagle sailed for its second voyage on December 27, I83I. The main purpose of this second expedition was to carry out hydrographic surveys at the coasts of South America, starting at the Río de la Plata down to Tierra del Fuego, ascending the west coast as north as possible and returning through the Pacific Ocean circumnavigating the Earth. Its captain, Robert FitzRoy, considered for this new voyage the necessity to count with a geologist on board. By John Henslow's recommendation ${ }^{6}$, the job was given to a young inexperienced naturalist who had recently graduated from university, Charles Darwin.

Charles Darwin, born in I809, had begun studying medicine at the University of Edinburgh (1825-1827) at his father's indication, but he left and later enrolled at Christ's College, University of Cambridge, for a Bachelor of Arts degree (I828-I83I), with the apparent idea of finally becoming an Anglican parson. At Edinburgh, Darwin became a student of Robert Grant ${ }^{7}$, a marine invertebrate zoologist. Grant was a friend and an advocator of the theories of Étienne Geoffroy Saint-Hilaire, while both were supporters of the theory of inheritance of acquired characteristics advanced by Jean-Baptiste Lamarck, a colleague of Geoffroy Saint-Hilaire at the Muséum National d'Histoire Naturelle, since its creation in I793. At Cambridge, Darwin became a student of John Henslow, a professor of botany, geologist and priest. During his years of study at Cambridge, Darwin became very acquainted with the works of William Paley, and expressed his admiration for Paley's logic and style in

\footnotetext{
${ }^{6}$ Charles Darwin was not the first choice. Henslow had offered the job to Leonard Jenyns first, a parsonnaturalist, but he declined the offer due to commitments to his parish.

7 The relation of Darwin with Grant was plague of conflicts in which Grant gave credit for himself of Darwin's discoveries.
} 
various occasions. Paley had explained the perfect and complex adaptation of organisms to their environments as evidence of a rational and intelligent predesign.

With this intellectual background, Darwin began his journey to South America on board of the Beagle, accompanied by Charles Lyell's "Principles of Geology" (first volume). Lyell was opposed to the transmutation of species and followed mainly the ideas of Cuvier regarding the existence of types that could vary slightly. In chapter 9 of the aforementioned book, Lyell discussed "the theory of the progressive development of organic life" from "the simplest to the most complicated forms".

On 26 July 1832, after landing in Bahia and Rio de Janeiro (Brazil), the Beagle reached Montevideo (Uruguay). From this strategic point, Darwin made various expeditions into Argentinean territories: Buenos Aires, Bahía Blanca, Punta Alta, Carmen de Patagones, ascended the Paraná River up to Santa Fe, and reached the southern territories of Puerto Deseado, Puerto San Julián, Tierra del Fuego and Islas Malvinas. At Punta Alta, Darwin found numerous fossils of large extinct mammals, such as the posteriorly described by Richard Owen Megatherium, Mylodon and Scelidotherium (Darwin I839, p. 95). By November Darwin received by mail the second volume of Lyell's "Principles of Geology". In this second volume, Lyell criticized Lamarck's "theory of transmutation of species". In the first chapter, he endeavored to discredit Lamarck's two principles of (I) "tendency to progressive development" and (2) "force of external circumstances" (Lyell I832, p. I3-I4). According to Lamarck, there was an internal force in nature that generated a progressive complexification of organization, evidenced as a scale of beings from the simplest to the most complex. This continuous scale of progressive complex organization was affected and interrupted by the external influence of the environment. Environmental changes generated different needs in organisms, these needs generated new habits, and these new habits produced organic modifications which were transmitted to the descendants. This second principle was commonly known as the "inheritance of acquired characteristics".

The development of the concept of natural selection and the dispute over the Malthusian influence

On 2 October $1_{3} 6$, the Beagle finally arrived back to England. Since his arrival, 
Darwin dedicated himself to write a manuscript with his observations as he was offered the opportunity to contribute with the natural history section to the captain's account of the voyage. He completed the manuscript by August September I837, and the text was finally published in I839 as the third volume of the series.

During that time lapse, many things happened and many conceptual transformations occurred. Darwin began to write his notebooks on "transmutation of species" in mid-r837. In the third notebook, in his entrance of 28 September i838, he recorded his reading of Malthus' "An essay on the principle of population". Much was debated regarding the contribution and importance of this reading for Darwin's development of the concept of natural selection, especially around the beginning of the r97os (Vorzimmer i969; Young I969; Herbert I97i; Gale 1972). The accent and axis of the debate was put on "how much" Darwin did actually need Malthus for his conceptual development. This approach based on the "influence" was a strategy that presupposed and tended to the relativization of the relationship. A more conceptual and structural study is demanded to comprehend this matter.

One thing generally assumed was that Darwin took knowledge of Malthus' essay content only in 1838 , and not before that date. This date was used as a reference point that enabled to establish and reconstruct what Darwin knew and developed before and after his reading of Malthus. For example, Gavin de Beer concluded that Darwin developed the concept of natural selection before this reading and Malthus provided Darwin only with the appropriate context for its application: "From the list of books read, appended to the Second Notebook, it is known that he did not read Malthus's Essay on Population before 3 rd October 1838 , from which it can be seen that the contents of the Third Notebook owe nothing to Malthus's work. It is therefore of great importance to note that Darwin hit on the principle of natural selection independently. After a consideration of changes resulting in the formation of new species, he wrote: "All this agrees well with my view of those forms slightly favoured getting the upper hand and forming species" (III I75)" (Darwin I969, p. I2I). Therefore, Malthus' essay "supplied him with the remaining piece that he required to complete the construction of his argument" (Darwin i969, p. 26). This strategy of reconstruction of Darwin's theory by pieces, as a jigsaw puzzle, was further developed by Vorzimmer. His conclusion was that "without 
doubt $[\ldots]$ the great watershed in the development of Darwin's evolutionary theory came with his reading of Malthus. Not only did Malthus provide a vital missing element, but it served to precipitate other, equally necessary, elements into their proper place in Darwin's thought" (Vorzimmer i969). He considered that Darwin was aware of the existence of a natural counterpart to artificial selection and that the concept of struggle for existence enabled him to apply this process in nature. In consequence, despite their difference in tone, Vorzimmer's conclusion was similar to de Beer's. Both assumed that Malthus provided a missing link to Darwin's theory, a piece that allowed arranging the rest in a coherent picture, and that he knew how to apply this piece only after his reading of Malthus in September I838. In this manner, they placed Malthusian ideas in Darwin's theory as a rather confirmatory role and nearly $a$ posteriori contribution.

Against this argument, Young (1969) warned about the fact that Malthus' "influence" was "pervasive in the biological literature of the first decades of the century". Even de Beer recognized that the concept of "struggle for existence was well known to Darwin" from the work, for example, of Lyell (Darwin ig69, p. 40). One could read in his "Principles of Geology": "In the universal struggle for existence, the right of the strongest eventually prevails; and the strength and durability of a race depends mainly on its prolificness, in which hybrids are acknowledged to be deficient" (Lyell I832, p. 56). As can be seen, Darwin would not only have received the concept of struggle for existence from Lyell, but also the concept of selectionism in nature. In fact, other people before Darwin had developed the concept of natural selection. Again, de Beer acknowledged this, but with reservations: "two contemporaries [Charles Lyell and Edward Blyth] recognized natural selection but used it to prove that evolution could not occur. Unknown to Darwin, two other men [William Wells and Patrick Matthew] had, before him, grasped the solution of the problem and stated that natural selection could cause modification of species; but they were very far from being able to appreciate the significance of what they had done, provide evidence to support it, or work out its consequences" (Darwin

\footnotetext{
${ }^{8}$ As stated before, this second volume was received and read by Darwin the same year of its publication in 1832.
} 
I969, p. 27).

Thomas Huxley also recognized that there were earlier antecedents of the concept of natural selection, such as those from William Wells and Patrick Matthew. For example, Wells affirmed: "those who attend to the improvement of domestic animals, when they find individuals possessing, in a greater degree than common, the qualities they desire, couple a male and female of these together, then take the best of their offspring as a new stock, and in this way proceed, till they approach as near the point in view, as the nature of things will permit. But, what is here done by art, seems to be done, with equal efficacy, though more slowly, by nature, in the formation of varieties of mankind, fitted for the country which they inhabit" (Wells I8ı8, p. 435). In later editions of the Origin, Darwin credited Wells for the recognition of the principle of natural selection. However, it was not a full credit but a partial and circumscribed recognition, as Darwin considered that "he applie[d] it only to man, and to certain characters alone" (Darwin i866, p. XIV).

One fact that has been overlooked up to now in this conceptual puzzle is that Darwin would not have needed to read Malthus' book in order to obtain the "missing link" or "ordering piece" for the development of his theory. This fact is that Darwin had already read Malthus' theory of population during his years of study at university, more precisely, immediately after having graduated at Cambridge in I831. The thing is that Paley in his "Natural Theology" (1802) expounded and discussed Malthus' theory: "The order of generation proceeds by something like a geometrical progression. The increase of provision, under circumstances even the most advantageous, can only assume the form of an arithmetic series. Whence it follows, that the population will always overtake the provision, will pass beyond the line of plenty, and will continue to encrease till checked by the difficulty of procuring subsistence ${ }^{9 "}\left(\right.$ Paley I802, p. 372) ${ }^{\text {10 }}$.

In consequence, Darwin had no priority over the concepts of transmutation of species and natural selection. Possibly, he could be credited for having

\footnotetext{
${ }^{9}$ At this point Paley introduced a footnote that said: "See this subject stated in a late Treatise upon Population" (Paley I802, p. 372), which was, in spite of its vagueness, a clear reference to Malthus' "An essay on the principle of population" (I798).

${ }^{\text {Io }}$ As far as I am concerned, this fact was not detected and exposed in the previous literature analyzing Malthus' influence on Darwin's theory.
} 
combined both. However, the purpose of this article is not to establish to whom these priorities corresponded, and who was the real precursor and father of these concepts. The purpose is to analyze where these concepts came from and how they developed. We have seen that natural selection, whenever it appeared, was always accompanied by the corresponding Malthusian concept of struggle for existence. Therefore, one fundamental question we should ask for is: could the concept of natural selection have been developed without the corresponding Malthusian concept? Could one exist without the other?

\section{Blyth and the creative power of natural selection}

It seemed that Darwin was not aware of the previous works of Wells (I8I8) and Mathews (I83I). However, the same argument could not be applied to Blyth. Darwin cited him various times in his notebooks on the transmutation of species. One could read in a paper published by Blyth in I835: "the original and typical form of an animal is in great measure kept up by the same identical means by which a true breed is produced ${ }^{\text {II }}$. The original form of a species is unquestionably better adapted to its natural habits than any modification of that form; and, as the sexual passions excite to rivalry and conflict, and the stronger must always prevail over the weaker, the latter, in a state of nature, is allowed but few opportunities of continuing its race. In a large herd of cattle, the strongest bull drives from him all the younger and weaker individuals of his own sex, and remains sole master of the herd; so that all the young which are produced must have had their origin from one which possessed the maximum of power and physical strength; and which, consequently, in the struggle for existence, was the best able to maintain his ground, and defend himself from every enemy. In like manner, among animals which procure their food by means of their agility, strength, or delicacy of sense, the one best organized must always obtain the greatest quantity; and must, therefore, become physically the strongest, and be thus enabled, by routing

\footnotetext{
"This mechanism had been explained earlier in that text: "When two animals are matched together, each remarkable for a certain given peculiarity, no matter how trivial, there is also a decided tendency in nature for that peculiarity to increase; and if the produce of these animals be set apart, and only those in which the same peculiarity is most apparent, be selected to breed from, the next generation will possess it in a still more remarkable degree; and so on, till at length the variety I designate a breed, is formed, which may be very unlike the original type" (Blyth I835, p. 45).
} 
its opponents, to transmit its superior qualities to a greater number of offspring. The same law, therefore, which was intended by Providence to keep up the typical qualities of a species, can be easily converted by man into a means of raising different varieties" (Blyth I835, p. 46). The concept of natural selection is clearly established and explained by Blyth in this excerpt. It is also suggestive that Blyth used exact Malthusian terminology for his explanation (i.e. struggle for existence).

Gavin de Beer assumed that "like Lyell before him, Blyth who believed in special creation used the principle of natural selection to prove that species were immutable" (Darwin I969, p. 36). This asseveration was rather hasty and in need of further consideration and analysis. Lyell was against a possible transmutation of species as this was necessary for supporting and being logically coherent with his theory of uniformitarianism (Darwin ig69, p. 33). Both considered that some degree of organic modification on species, although restricted and limited, was possible, they considered them as varieties and, as such, as deviations from a prototype or original type. Blyth clearly established the principle of natural selection, its proper functioning and application, although he did not give a specific term for it. Now, at first glance, there seemed to be some logical inconsistency in his argument. Blyth thought that this was the law used by nature to keep up the species (Blyth i835, p. 46). Then, it seemed that he used the same principle or law for explaining how species deviated from their original type and for explaining how they were maintained. However, the inconsistency is only apparent. Blyth considered that species could be artificially modified by the same principle acting in nature, but as "the original form of a species is unquestionably better adapted to its natural habits than any modification of that form", artificial selection was as an unstable process that was always "reversed" by the principle of natural selection, if for example a domesticated animal was put again into its natural habitat. It is in this sense that we could assert that Blyth's principle was conservative. But this was not all, as his principle was conservative for another reason. Actually, Blyth believed that such a principle was not a creative factor. In other words, he believed that this process had not a modifying effect. Eiseley (I959) remarked that Blyth "saw natural selection as pruning out the least deviation which threatened to unfit the animal for its environment". Therefore, natural selection acted as a filter that eliminated the least fitted variants. For Eiseley, this restriction was a 
limitation in Blyth's thinking and "it was Darwin's contribution, of course, that he altered the struggle for existence and made of it a creative mechanism" (Eiseley 1959). This question requires a further and deeper analysis.

I agree with Eiseley in that Blyth saw natural selection as a filtering, discarding and eliminative process and that Darwin pretended to adjudicate and endow it with a creative and modifying power. However, contrary to Eiseley's assumption that Darwin's contribution implied a clear step forward with respect to Blyth's version, I consider Darwin's pretension ambiguous and problematic. Along the Origin of species, Darwin continuously and alternatively adjudicated to natural selection a preserving or a modifying activity ${ }^{12}$. Even in

${ }^{\text {I2 }}$ For example: "I have called this principle, by which each slight variation, if useful, is preserved, by the term of Natural Selection, in order to mark its relation to man's power of selection" (Darwin I859, p. 6I), "this preservation of favourable variations and the rejection of injurious variations, I call Natural Selection" (Darwin I859, p. 8I), "for natural selection to fill up by modifying and improving some of the varying inhabitants" (Darwin I859, p. 82), "it may be said that natural selection is daily and hourly scrutinising, throughout the world, every variation, even the slightest; rejecting that which is bad, preserving and adding up all that is good; silently and insensibly working, whenever and wherever opportunity offers, at the improvement of each organic being" (Darwin I859, p. 84), "natural selection will be enabled to act on and modify organic beings at any age, by the accumulation of profitable variations" (Darwin I859, p. 86), "natural selection may modify and adapt the larva of an insect to a score of contingencies" (Darwin r859, p. 86), "natural selection will modify the structure of the young in relation to the parent, and of the parent in relation to the young" (Darwin i859, p. 86), "a structure used only once in an animal's whole life, if of high importance to it, might be modified to any extent by natural selection" (Darwin I859, p. 87), "natural selection can act only by the preservation and accumulation of infinitesimally small inherited modifications, each profitable to the preserved being" (Darwin I859, p. 95), "natural selection will always tend to preserve all the individuals varying in the right direction" (Darwin 1859, p. I02), "natural selection be modifying and improving a species in the several districts" (Darwin 1859, p. I02), "natural selection always tending to modify all the individuals in each district in exactly the same manner to the conditions of each" (Darwin I859, p. I03), "natural selection acts solely through the preservation of variations in some way advantageous, which consequently endure" (Darwin I859, p. Iog), "new species in the course of time are formed through natural selection" (Darwin I859, p. II0), "natural selection acts through one form having some advantage over other forms in the struggle for existence, it will chiefly act on those which already have some advantage" (Darwin I859, p. I25), "this principle of preservation, I have called, for the sake of brevity, Natural Selection. Natural selection, on the principle of qualities being inherited at corresponding ages, can modify the egg, seed, or young, as easily as the adult" (Darwin 1859, p. 127), "natural selection seems to have struggled with the loss of light and to have increased the size of the eyes" (Darwin 1859, p. I37), "natural selection will often have effected other changes" (Darwin I859, p. I38), "natural selection will continually tend to preserve those individuals which are born with constitutions best adapted to their native countries" (Darwin I859, p. I42), "an ancient progenitor may have acquired through natural selection some one modification in structure" (Darwin I859, p. I46), "natural selection may perfectly well succeed in largely developing any organ" (Darwin 1859, p. I48), "natural selection should have preserved or rejected each little deviation of form" (Darwin I859, p. I49), "natural selection acts solely by the preservation of profitable modifications" 
the title of his work this ambiguity remained: "On the origin of species by means of natural selection, or the preservation of favoured races in the struggle for life", trying to equalize the generation of new species to their preservation. What it is problematic about this equalization is that selection is an a posteriori process. Selection can only be exerted on what is already generated. Darwin himself made this point very clear on numerous times: "unless profitable variations do occur, natural selection can do nothing" (Darwin I859, p. 82). Therefore, it cannot be concluded that "selection was the principle of change" (Darwin rgo3, vol. I, p. iा8).

Another important point regarding this issue is if it is possible to conceive a natural counterpart to artificial selection. Young (197I) asked himself: "Does nature select?". For Darwin, the answer was affirmative. In fact, his theoretical developments followed the line of this assumption, at least as he himself recognized in retrospective: "You are right, that I came to the conclusion that selection was the principle of change from the study of domesticated productions" (Darwin I903, vol. I, p. i 18). From its conception, the principle of natural selection has been accused of personifying nature: selection required a selector, in this case nature itself. Darwin responded and defended against these accusations alleging that it was only a metaphor: "Several writers have misapprehended or objected to the term Natural Selection. Some have even

(Darwin 1859, p. 172), "it would be easy for natural selection to fit the animal, by some modification of its structure, for its changed habits" (Darwin I859, p. I83), "I can see no very great difficulty (not more than in the case of many other structures) in believing that natural selection has converted the simple apparatus of an optic nerve merely coated with pigment and invested by transparent membrane, into an optical instrument as perfect as is possessed by any member of the great Articulate class" (Darwin I859, p. I88), "there seems to me to be no great difficulty in believing that natural selection has actually converted a swimbladder into a lung" (Darwin I859, p. I9I), "I do not doubt that little folds of skin [...] have been gradually converted by natural selection into branchiae" (Darwin I859, p. 192), "natural selection acts by life and death, by the preservation of individuals with any favourable variation, and by the destruction of those with any unfavourable deviation of structure" (Darwin 1859, p. 194), "we may infer that these several bones might have been acquired through natural selection" (Darwin 1859, p. 200), "natural selection can and does often produce structures for the direct injury of other species" (Darwin 1859, p. 200), "natural selection acts only by the accumulation of slight modifications of structure or instinct" (Darwin I859, p. 233), "the theory of natural selection is grounded on the belief that each new variety, and ultimately each new species, is produced and maintained by having some advantage over those with which it comes into competition; and the consequent extinction of less-favoured forms almost inevitably follows" (Darwin I859, p. 320), "old forms having been supplanted by new and improved forms of life, produced by the laws of variation still acting round us, and preserved by Natural Selection" (Darwin r859, p. 345). 
imagined that natural selection induces variability, whereas it implies only the preservation of such variations as arise and are beneficial to the being under its conditions of life. No one objects to agriculturists speaking of the potent effects of man's selection; and in this case the individual differences given by nature, which man for some object selects, must of necessity first occur. Others have objected that the term selection implies conscious choice in the animals which become modified [...] Everyone knows what is meant and is implied by such metaphorical expressions; and they are almost necessary for brevity. So again it is difficult to avoid personifying the word Nature; but I mean by Nature, only the aggregate action and product of many natural laws, and by laws the sequence of events as ascertained by us. With a little familiarity such superficial objections will be forgotten" (Darwin 1871, p. 85) ${ }^{13}$. However, Darwin's justification is insufficient. The problem is not the term itself or if it is a metaphor or not, the problem is what it is implied, the attributes and characteristics conferred to that term or metaphor. One of the best characterizations given by Darwin to his principle was the following: "One may say there is a force like a hundred thousand wedges trying [to] force every kind of adapted structure into the gaps in the oeconomy of nature, or rather forming gaps by thrusting out weaker ones" (Darwin I967, p. I63). In this characterization, natural selection appeared as a filtering device which activity consisted of discarding the structures that did not conform to its imposed conditions. This explanation contained a metaphor, i.e. nature acting as a filter, but this metaphor did not imply judgment or valuation. A filter does not judge or valuate. In any case, the filter's maker can prepare the filter so as to obtain a desired or expected product. Therefore, in a strict sense, a filter cannot select but only discard, "thrust out", only the filter's maker can. If nature was considered as "only the aggregate action and product of many natural laws, and by laws the sequence of events as ascertained by us", nature cannot select. In consequence, the conflict with the term "natural selection" is not its metaphorical content, but the concession and endowment of attributes and properties incompatible with the intended metaphor.

\footnotetext{
${ }^{13}$ In this excerpt from the $5^{\text {th }}$ edition (I87I) of the Origin of species, it can be detected the same ambivalence and ambiguity mentioned before, regarding the real activity of a process such as natural selection, i.e. preservation or modification, in this case favoring the first one.
} 


\section{The value judgments of natural selection}

Darwin, in spite of continuously acknowledging a preserving activity to natural selection, conferred it repeatedly with the capacity of making value judgments. For example, he asserted that "natural selection will never produce in a being anything injurious to itself, for natural selection acts solely by and for the good of each. No organ will be formed, as Paley has remarked, for the purpose of causing pain or for doing an injury to its possessor" (Darwin I859, p. 20I). Nature was then posited as the censor, the guarantor and securer that only the most deserving beings were going to be selected and survive. This scenario did not differ substantially from the one proposed by Malthus: "Nature, in the attainment of her great purposes, seems always to seize upon the weakest part. If this part be made strong by human skill, she seizes upon the next weakest part, and so on in succession; not like a capricious deity, with an intention to sport with our sufferings, and constantly to defeat our labours; but, like a kind, though sometimes severe instructor, with the intention of teaching us to make all parts strong, and to chase vice and misery from the earth. In avoiding one fault we are too apt to run into some other; but we always find Nature faithful to her great object, at every false step we commit, ready to admonish us of our errors, by the infliction of some physical or moral evil" (Malthus I826, vol. 2, p. 304). At this stage, it is where the hidden face of Darwin's proposal reveals itself, where its ideological matrix is unmasked and exposed. At bottom, Darwin's proposal was an ideology-loaded and value-driven theory: nature was the personification of the ideology and values of the author and the society where he lived, which was fully expressed in Malthus' Essay on population.

Malthus' principle of population was a principle that secured that only the most valuable individuals were able to survive: "A horse or any other working animal is said to be strong only in proportion to the strength of his weakest part. If his legs be slender and feeble, the strength of his body will be but of little consequence; or if he wants power in his back and haunches, the strength which he may possess in his limbs can never be called fully into action. The same reasoning must be applied to the power of the earth to support living creatures" (Malthus I826, vol. I, p. I39) ${ }^{14}$. In this manner, the principle of

\footnotetext{
${ }^{14}$ Subsequently, he gave an example of this assertion: "The Tartar therefore provides only for the most valuable of his cattle during the winter, and leaves the rest to support themselves by the scanty herbage
} 
population was exerted with severity against the lowest classes of society, whereas the higher classes were more prepared to face this oppressive natural law. For Malthus, this natural state was just and justified: "We have seen the fatal effects that would result to a society, if every man had a valid claim to an equal share of the produce of the earth. The members of a family which was grown too large for the original division of land appropriated to it, could not then demand a part of the surplus produce of others, as a debt of justice. It has appeared, that from the inevitable laws of our nature, some human beings must suffer from want. These are the unhappy persons who, in the great lottery of life, have drawn a blank" (Malthus I789, p. 204).

Therefore, the ultimate objective of this intellectual endeavor was to establish the values of liberal economy as natural laws. According to Destutt de Tracy, from feeling arised will, from will arised the ideas of personality and property, and with them the idea of the self: "The idea of property arises then solely from the faculty of will; and moreover it arises necessarily from it, for we cannot have an idea of self without having that of the property in all the faculties of self and in their effects. If it was not thus, if there was not amongst us a natural and necessary property, there never would have been a conventional or artificial property" (Destutt de Tracy i8izb, p. XII). Will rendered us susceptible to the satisfaction of wants and needs, that is, to the possession of goods, and "to be rich is to possess these goods; to be poor is to be without them" (Destutt de Tracy i8I7b, p. XIII), and this depended solely on the employment of our faculties. In this manner, social inequality was natural as it proceeded from our differential inborn faculties. If it was natural, it was inevitable, and in a world where resources were limited, the only possible outcome was competition, the struggle among individuals and the survival of the "fittest".

which they can pick up. This poor living, combined with the severe cold, naturally destroys a considerable part of them" (Malthus i826, vol. I, p. I40). There are numerous examples of this kind throughout his work. 


\section{IMMUNITY OR THE STRUGGLE WITHIN}

\section{The birth of immunology: Mechnikov's introduction of Darwin's theory in pathology}

It is commonly held that the birth of the science of immunology was Edward Jenner's discovery of "variolisation" or "inoculation", i.e. vaccination, in I796. As Mechnikov himself recognized, this was a practice known from centuries coming from the East (China): "Variolisation or "inoculation" coming to Europe from the East, had come into extensive use when, at the end of the i8th century, the discovery was made that cow-pox, the varioliform disease of the Bovidae, produced in persons who milked cows suffering from this eruption an immunity against small-pox.. This idea, popular in origin, was known to breeders in England, France, Germany, and Holland; we have thus an indication that this knowledge must date from a fairly distant period. Jenner gave the question a scientific and experimental basis" (Metchnikoff i905, p. 455). Therefore, vaccination was practiced in China since the I ${ }^{\text {th }}$ century, and was a popular knowledge among breeders at the time Jenner underwent his experiments. In consequence, was vaccination a process coupled to the one described previously, that is, animal domestication, for the improvement of species and the production of desired characteristics?

As a result of the previous account, Mechnikov believed that also immunity existed "from time immemorial" and that it should be of "as ancient date as [was] disease" (Metchnikoff i905, p. 545). We are not sure about that, especially when one read the following immediately afterwards: "The most simple and the most primitive organisms have constantly to struggle for their existence; they give chase to living organisms in order to obtain food, and they defend themselves against other organisms in order that they may not become their prey. When the aggressor in this struggle is much smaller than its adversary the result is that the former introduces itself into the body of the latter and destroys it by means of infection" (Metchnikoff I905, p. 545). In this context, Mechnikov introduced the concept of struggle for existence in infectious diseases, and with it a whole arsenal of military conceptology and vocabulary: "But infection also has its counter. The attacked organism defends itself against the little aggressor. It protects itself by interposing a resistant membrane, or it uses all the means at its disposal to destroy the invader. As a very large number of organisms, in order to obtain nourishment, are obliged to submit their food to digestion by various 
chemical substances, they utilise these substances in the struggle against the infective agents" (Metchnikoff I905, p. 545). The need of defending themselves from invasive microorganisms pointed to the existence of a potential arsenal of mechanisms that allow organisms to prevent their usurpation, and the birth of immunology as a new branch of natural science occurred.

\section{Mechnikov and his early critics to Darwin's theory}

The case of Ilya Mechnikov is paradigmatic. In his youth he was a critic of Darwin's theory, his principle of natural selection and the introduction of Malthus' doctrine in biology. However, in his adulthood, after being established in Paris, holding a place of honor at the Pasteur Institute and winning a Nobel Prize, he became an advocator of Darwin's theory (Todes I989, p. 82).

In 1876 Mechnikov wrote a paper entitled "Essay on questions about the Origin of Species" in which he analyzed Darwin's work and found various inconsistencies and contradictions. For example, Darwin justified the relative lack of new species among freshwater forms and lower organisms by their geographical isolation from potential competitors. According to Mechnikov, this circumstance, on the contrary should be ideal for the production of new species: "here Malthus's law, which constitutes such an important foundation of Darwinism, is forgotten [...] From a truly Darwinist point of view the competitors are largely individuals of one and the same species, Amphioxus itself. If it lives in isolation it should multiply without hindrance in a geometrical progression, and this circumstance should in itself lead to variations" (Mechnikov, cited in Todes i987).

In spite of the many criticisms and deficiencies found in Darwin's work, Mechnikov found the concepts of natural selection and struggle for existence useful and pertinent and tried to purify them and eliminate their errors and incongruencies. Mechnikov did not consider that high reproduction and overpopulation were the causes of the struggle for existence. In order to support this argument, Mechnikov referred to Darwin's explanation for the stability of freshwater plants: "All fresh-water basins, taken together, make a small area compared with that of the sea or of the land; and, consequently, the competition between fresh-water productions will have been less severe than elsewhere; new forms will have been more slowly formed, and old forms more 
slowly exterminated" (Darwin I859, p. I07). Mechnikov found a contradiction in this explanation: "Here Malthus's law, which constitutes such an important foundation of Darwinism, is forgotten: limited space should most of all strongly facilitate overpopulation (as we do in fact see in reality) and overpopulation should stimulate the formation of new characteristics and the decline of old species in favor of new ones. If this is not so, if competition between different organisms is necessary for the formation of new species, then clearly the factor of overpopulation falls to the background in transformism" (Mechnikov, cited in Todes I989, p. 89). Conversely, Mechnikov considered that the cause of the struggle for existence was the satisfaction of the organisms' needs: "one can explain the universality of the struggle for existence without accepting the view that the earth is overpopulated and that struggle is always generated by the extreme, urgent need for a piece of bread" (Mechnikov, cited in Todes I989, p. 90). In consequence, conflict was inherent to nature and arised, not from a "disproportion between population and food supply", but "from contradictory aspirations and requirements within a given population" (Todes I989, p. 9I).

\section{The struggle between the own and the foreign}

In I874 Mechnikov published "General essay on the life of parasites". In this paper, Mechnikov studied the relation between parasites and their hosts, as a model of interaction between different species (interspecific). Mechnikov considered that this interaction was a struggle for existence, in which not always the most complex organism succeeded. Consequently, natural selection could not explain "the progressive development of organisms" which seemed to depend "upon a special tendency to perfection" (Todes I989, p. 92).

In the late I87os, Mechnikov changed his research interests from purely morphological-embryological investigations to studies in the phylogenetic development of the digestive system in lower organisms, with the idea of shedding a new light in evolution. It was in 1883 when Mechnikov made the major discovery of his career, the formulation of the phagocytic theory. According to this theory, inflammation was a struggle between the organisms' white cells and a parasite. In other words, Mechnikov established a link between digestion and defense, a connection illuminated by the concepts of struggle for existence and natural selection. 
As a zoologist venturing into the domain of pathology, Mechnikov intended to introduce the concepts of Darwinian evolution into the processes of health and disease. He considered that a new branch of science was needed to be created for this purpose, a science he called Comparative Pathology, and which he considered to be a branch of zoology. This science should study the evolution of pathological processes from the simplest forms of life to the higher animals. The foundational idea from which Mechnikov built his conceptual framework was that an infectious disease was an interspecific struggle: "If we examine the organisation of an animal or a plant, we find that their most characteristic features are their organs of attack and defence. The carapace of the crayfish, the shell of molluscs and the teeth of the vertebrates, as well as many other organs, are so many means of protection to these animals in their perpetual warfare [...] Now from active aggression to infection, there is but a short step" (Metchnikoff I893, p. 2). Therefore, zoology should take pathology into consideration: "Since zoological research takes cognisance of the phenomena of attack and defence, it should likewise include the processes of infection and resistance, which are really in such close connection with the former. The phenomena of the active struggle among animals, however, being much more prominent, have attracted the attention of naturalists for years, whereas those of infection, which are far less on the surface, have been but rarely and insufficiently studied" (Metchnikoff ı893, p. 3). Thus, infection was a struggle between organisms that has become internal: the enemy was now within. In this case, the pathogen should have adaptations that enabled it to penetrate and remain in the host, and the host should have mechanisms that served to resist invasion.

Mechnikov explicitly acknowledged that this new science was based on Darwin's theory: "The groundwork of such a comparative pathology was laid about five-and-thirty years ago. About this time, in 1857 and I858, the theory of natural selection was built up on scientific foundations by Darwin and Wallace, the biological theory of fermentation by Pasteur, and the theory of cellular pathology by Virchow" (Metchnikoff I893, p. 4). Moreover, he left no doubt that he considered Darwin's theory as the most fundamental theory of biological sciences: "The first of these theories, which now forms the basis of all biological research, proved the genealogical evolution of organized beings, and 
explained the adaptation of means to an end observed in them. It demonstrated that only the characteristics which are advantageous to the organism survive in the struggle for existence, while those that are harmful to the individual are readily eliminated by natural selection" (Metchnikoff ı893, p. 4).

The biological phenomenon chosen by Mechnikov to study and advance with this new branch of science was inflammation, which was for him "the most important phenomenon in pathology". It was already acknowledged that inflammation was a process in which hyperemia and exudation occurred at the site of lesion, and that the cells in this exudation arised from the "white corpuscles" of the blood. It was considered that exudation was triggered by a lesion on the vessels, which rendered them more permeable and allowed the fluid and corpuscular elements of the blood to flow through them in a passive manner. It was then investigated inflammation in parts of the body devoid of blood vessels and demonstrated that vascular disturbances were not essential for inflammation to take place. The discovery of karyokinesis enabled to prove that this was produced by division of local tissue cells. This was interpreted mainly as a process of reparation. Therefore, the inflammatory process was considered to consist of two instances: I) inflammation, the lesion and disturbances produced by the irritating cause; and 2) reparation, the regeneration of missing tissues and formation of the scar. Thus, it did not only include the disorders occasioned by the foreign agent, but also the processes of recovery that led to its cure. There was some debate regarding if some primary processes of inflammation, such as cell migration to the site of infection, should also be considered as part of the reparatory responses triggered to reestablish the damage initiated by the intruder. In consideration of all the above, Mechnikov arrived at the conclusion that the process of inflammation was so complex and variable in its manifestations, that simpler experimental models should be developed in order to study it more properly by eliminating variables. In this regard, Mechnikov even considered that the term "inflammation" should be discarded, in view that this process was also evident in cold-blooded animals and therefore the word was no longer applicable in its 
etymological sense ${ }^{15}$. Then, Mechnikov's strategy was to investigate the process of inflammation in lower members of the animal kingdom, including invertebrates, in order to trace and detect the existence of these phenomena characteristic of higher animals.

The evolutionary study of inflammation starting from the lowest organisms up to vertebrates, led Mechnikov to propose his own theory of inflammation. He found that inflammation was a process found even in the lowest organisms and it was not a passive process provoked by a vascular lesion, but actually a reactive organismal response triggered by the invasion of a foreign intruder, that is, a defensive countermeasure in an interspecific struggle. Moreover, he proposed that the most fundamental factor during an inflammation was the digestion of the invasive agent by phagocytic cells, such as leucocytes: "the essential and primary element in typical inflammation consists in a reaction of the phagocytes against a harmful agent" (Metchnikoff I893, p. I87). Subsequently, he left no doubt by affirming: "the essential phenomena of inflammation represent an actual struggle between the phagocytes and the irritant agent" (Metchnikoff ı893, p. I89). These conclusions constituted what he would call the phagocytic theory.

Strangely as it may seem today, Mechnikov's theory was accused of being teleological and vitalistic. The debate was interesting. According to Mechnikov, Fränkel criticized his theory in these terms: "The phagocyte theory presupposes extraordinary powers on the part of the protoplasm of leucocytes, to which are attributed sensations, thoughts and actions, in fact a kind of psychical activity" (Metchnikoff I893, p. I92). To this, Mechnikov responded: "The sensibility of the phagocytes is not an hypothesis which can be admitted or rejected at will, but an established fact, which cannot be ignored, as it is by Frankel. Whether they possess powers of thought and volition, as this author accuses me of assuming, is quite beside the question, though we are justified in considering that they possess a germ of these qualities and that their sensibility, like that of various vegetable and animal unicellular organisms represents the lowest stage in the long series of phenomena which culminate in the psychical activities of

\footnotetext{
I5 The term "inflammation" was derived from the Latin word inflammatio, which meant "inflaming", "setting a fire".
} 
man" (Metchnikoff I893, p. I92). He called the authorities of Herbert Spencer and George Romanes in order to assert that psychical phenomena had no specific quality or status, but they developed as associations of simple actions. He also called Darwin's theory in his defense against his critics: "This theory is based on the law of evolution according to which the properties that are useful to the organism survive while those which are harmful are eliminated by natural selection. Those of the lower animals which were possessed of mobile cells to englobe and destroy the enemy, survived, whereas others whose phagocytes did not exercise their function were necessarily destined to perish. In consequence of this natural selection the useful characteristics, including those required for inflammatory reaction, have been established and transmitted, and we need not invoke the assistance of a designed adaptation to a predestined end, as we should from the teleological point of view" (Metchnikoff I893, p. I93). According to Mechnikov, therefore, natural selection saved him from falling into teleological arguments.

\section{From the concept of immunity to the immune self}

The introduction of the concepts of struggle for existence and natural selection into immunology, led to conceive this new field as the struggle against foreign pathogens. The almost inevitable logical consequence of this assumption was that it was necessary, therefore, to possess mechanisms that distinguish between the harmless own interior and the potentially harmful foreign exterior. This presupposed a sharp and exclusive separation among the different organisms, a presupposition that was also necessary for a process such as natural selection, in which the different individuals should be put one beside the other in order to compete for resources and prevail based on proclaimed individual superior qualities.

Although the concept of immune self was going to be developed fully by Frank Burnet in the I950s (Tauber, 2000), in the so-called clonal selection theory (CST), rudiments of this concept can be detected in Mechnikov's phagocytosis theory (Tauber, 2003). Indications of this concept could be contained in his repeated usage of the term "itself". One example of this is the passage cited before: "But infection also has its counter. The attacked organism defends itself against the little aggressor. It protects itself by interposing a 
resistant membrane, or it uses all the means at its disposal to destroy the invader" (Metchnikoff i905, p. 545) ${ }^{16}$.

Roberto Espósito explained that the term immunity derived from the Latin immunitas, and ultimately from munus, being immunitas the negation or lack of munus. According to Espósito, basing himself on its Latin meaning and usage, munus was a duty, obligation, burden or service, being therefore a term associated to legal and tax issues, and immunitas the exemption of that legal or tax duty: "The Latin dictionaries teach us that the noun immunitas, as its corresponding adjective immunis, is a privative, or negative word that derives its meaning from that what it denies, or from what it lacks, that is, the munus. If one examines the prevailing meaning of this latter term, one obtains by contrast that of immunitas: with respect to "function", charge, obligation, duty (also in the sense of a gift to be restored), represented by the munus, it is called immune, conversely, to whom is not in charge of any obligation. The one that is free of onus, exonerated, "dispensed" from the payment of taxes or benefits to others. It is immune who owes nothing to anyone according to the double meaning of vacatio and excusatio: whether it is original autonomy or the waiver of a debt previously contracted, what counts in determining the concept is to be exempt from the obligation of munus, whether personal, fiscal or civil" (Espósito, 2009, p. I4).

This etymological analysis could be continued and carried out further. If one does this, one finds that the Latin term munus derived from the Greek term $\mu$ óvos, which meant only, unique, single. In turn, this term derived from the root mey-, which meant bind. Then, immune was unbound, and therefore, a separated, isolated, excluded individual. In this manner, the salient feature of this concept would be that of exclusion, rather than that of exemption. The model for a concept such as immunity would be that of disjoint sets, that is, sets with no common elements and, therefore, no intersection. If this concept is privative or negative is because it is the ultimate redoubt of being. The concept of self seems to follow naturally from the concept of immunity because it itself

I6 Other examples are: "the organism has elaborated means to defend itself against its aggressors" (Metchnikoff I893, p. I08). 
derives, in an initial analysis, from being apart and separate ${ }^{17}$. However, and again, this concept could be analyzed further.

The root from which the term self derived, which correspondence in Greek is $\ddot{\varepsilon}(h \hat{e})$, is, in fact, a reflexive pronoun. This particle was then coupled with the demonstrative pronoun ö $(h o ́ s)$, obtaining the resulting possessive pronoun غ̇ós (heós). In this manner, an originally reflexive concept was transformed into a possessive one: the self was now to be interpreted as my-self. An originally dynamic reflexive concept was transformed, through an initial objectification by means of demonstration ${ }^{18}$, into an invariable and static possessive concept.

Therefore, thinking of the self as an entity which separates us and sets us apart is not the only way that it could be conceived. The self could be that which we allow us to reflect and see ourselves reflected in others. This gives us the sense that we have things we share and things we have in common, that is, to feel empathy for others. Ultimately, our sense of identity is what allows us to identify ourselves with others.

\section{IDEOLOGY: A SGIENGE OF IDEAL VALUES}

The works of Destutt de Tracy proposed a science of material values, measured by its degree of utility. For this ideology, ideas were exchangeable commodities, and a valuable idea was a useful idea. To this ideology it should be counterproposed an ideology of ideal values. For this new concept of ideology, ideas are value-driven directed activities. All ideas presuppose and contain values that direct our actions and activities.

Antecedents to this proposal could be found, for example, in the so-called "theory of the two sciences" of Alexander Bogdanov (Ostachuk 2015a, 2015b). Bogdanov proposed that science was a human endeavor driven by ideology and that, in this manner, every class of society would develop its own particular and specific scientific investigations according to their ideological background. For Bogdanov, "ideologies are organizing forms for the entire practice of society or, what is the same thing, its organizational instruments" (Bogdanov

\footnotetext{
${ }^{17}$ The etymological sequence would be: self $\rightarrow$ selbaz $\rightarrow$ selb- $\rightarrow$ swe- (separate, apart).

${ }^{\text {I8 }}$ Demonstrative pronouns are those of which we serve to show the objects indicating their situation with respect to a certain person.
} 
I984, p. 48). He gave a big step forward with this definition. For both Destutt de Tracy and Bogdanov, everything was ultimately ideological, but for very different reasons. For Destutt de Tracy, ideas were perceptions coming from the senses and whose value resided in their utility, what rendered them as exchangeable commodities for making profit. For Bogdanov, ideas were the products of organized experience, that is, the result of a production accomplished by social cooperative and interactive work. An idea was an "organizational scheme, whether it comes out in the form of a technical rule, scientific knowledge or artistic conception", which "coordinates the efforts of people in a direct and manifest fashion", and "serves as a living means of rallying the collective toward a unity of perception, feeling and mood; it rears an individual for his life in society, prepares the organizational elements of the collective and introduces them into its internal order" (Bogdanov I984, p. 3). For Bogdanov, ideas arised ultimately from active human social praxis, not from a passive individual perception from the senses.

Bogdanov, influenced by his historical materialism, could not go much further. In spite of being accused of idealist by his comrades for following Mach's ideas, his theory for the creation of ideas remained purely materialistic: ideas originated from concrete, real practice ${ }^{19}$. However, he admitted that these materially-born ideas could then be transformed into ideals for the assembly and inspiration of society. A growing, striving collective contained "socially practical and actively organizational ideals" (Bogdanov i984, p. I20). He even ventured to affirm that "the pinnacle of each ideology, its highest characteristic, lies in the vital ideal' (Bogdanov i984, p. I20).

Therefore, values are ideals that inspire our actions. They constitute an ideological matrix in which we are imbued and from which they exert a numinous power that impel us to act in a given way. In this regard, it is an axiological matrix ${ }^{20}$. This matrix is a plexus, a pleroma, an interwoven web which nodes or knots are the enfolded values, as seminal reasons, waiting to be developed and actualized by a subject who came under its influence and

\footnotetext{
${ }^{19}$ His materialism also led him to adopt the concepts of "struggle for existence" and "natural selection".

${ }^{20}$ Axiology comes from the Greek term $\dot{\alpha} \xi \hat{i} \alpha$, which means value. But there is more: this term, in turn, derives from $\alpha$ $\gamma \omega$, which means to lead, carry with, guide. Therefore, values carry in their own term their capacity to induce and direct.
} 
charm. Once we are captivated under the influence of an ideal value, we do not simply perform it or actualize it, it would be more appropriate to say that the value is performed and actualized through ourselves. We become the simple instruments or organs of its whim. In other words, ideal values are normative.

The existence and factuality of this matrix can be evidenced simply by viewing how the world is now. By doing this, we will only see realizations and actualizations of values derived from materialism. We will see commodities loaded with an exchange or monetary label, and not only material objects but also immaterial ones, including knowledge.

\section{GONCLUSION}

In this work we have shown that Darwin read Malthus much earlier than it had been determined. Malthus' theory was contained and summarized in Paley's "Natural Theology", which Darwin read in i83 I. Moreover, we have demonstrated that there is a logical necessity of the concept of struggle for existence, for Darwin being able to develop his concept of natural selection: the second could not have been developed without the first one. In this manner, Malthus' theory was not the missing piece for Darwin's final and definite concrescence, but a real logical antecedent. The same applies to Mechnikov, who required the concepts of struggle for existence and natural selection for the development of his concept of immunity.

Ultimately, it does not matter if Darwin read Malthus before or after his conceptual developments, if this reading was indispensable or not, etc. The reality is that there were various antecedents to Darwin's concept of natural selection. There was a growing conceptual trajectory that led to Darwin's final concretion. And this trajectory was guided and directed by the same values: individual interest, inevitable inequality, property, utility and profit. With these interests, it was inevitable to picture a world where the most gifted, and the ones who could best profit from their utilities, would survive. And all this was not "natural", they were not ideas provided by the senses, they were ideas provided by their values. It was not just a simple (and recurrent) coincidence that advocators of social inequality considered it as "natural". Their values determined their ideas, which, in turn, served to justify and substantiate their 
values. But under this materialistic view, the most gifted were, in fact, the most learned $^{21}$. Therefore, their prevalence came from their apprehension, appropriateness and privilege. The paradox of this proposal is that the more you take and own, the more idiot you become ${ }^{22}$.

The proposal of an ideological matrix is also important for science policy making. It shows that there are other values that could drive science and stimulate other scientific endeavours. Science policy should rely not on the applicability of certain knowledge, but on the values that direct it. We still live in a society whose imbued values tell us that social inequality is natural and that selection is a creative process that leads to progress. The truth is that selection is a filtering and discarding process that sustains, accentuates and aggravates social inequality. Values are ideals that constitute an ideological matrix that exerts a numinous activity and inspire us and impulse us towards certain directions.

Museo de La Plata (MLP), Universidad Nacional de La Plata (UNLP), Buenos Aires, Argentina Centro de Estudios de Historia de la Ciencia y de la Técnica José Babini, Universidad Nacional de San Martín (UNSAM), Buenos Aires, Argentina aostachuk@unsam.edu.ar

\section{REFERENCES}

Blyth, E. (1835). An attempt to classify the "varieties" of animals, with observations on the marked seasonal and other changes which naturally take place in various British species, and which do not constitute varieties. The Magazine of Natural History, 8, 40-53.

Bogdanov, A. (1984). Essays in Tektology: the general science of organization. Seaside: Intersystems Publications.

\footnotetext{
${ }^{21}$ This is an inevitable logical consequence of a sensionalist epistemological framework, such as the one followed by Locke, Condillac and Destutt de Tracy. It is also a philological pun. The term gift derives ultimately from receive, whereas the term learn derives ultimately from apprehend, take or get.

${ }^{22}$ Another philological pun: the term idiot derives from the Greek $\mathfrak{i} \delta \mathfrak{i} \grave{\omega} \tau \eta \varsigma$ (idiotes), which meant proprietor and owner.
} 
Darwin, C. (I839). Fournal of researches into the Natural History and Geology of the countries visited during the voyage of HMS Beagle. London: Henry Colburn.

Darwin, C. (1859). On the origin of species by means of natural selection, or the preservation of favoured races in the struggle for life. London: John Murray.

Darwin, C. (1866). On the origin of species by means of natural selection, or the preservation of favoured races in the struggle for life, $4^{\circ}$ edition. London: John Murray.

Darwin, C. (1903). More letters of Charles Darwin. Vol. I. London: John Murray.

Darwin, C. (1969). Darwin's notebooks on transmutation of species. Bulletin of the British Museum (Natural History), Historical Series, 2.

Darwin, C. (1967). Darwin's notebooks on transmutation of species. Bulletin of the British Museum (Natural History), Historical Series, 3(5), I29-176.

Destutt de Tracy, A. (1796). Mémoire sur la faculté de penser. Mémoires de l'Institut National des Sciences et Arts: Sciences Morales et Politiques, I, 283-450.

Destutt de Tracy, A. (1817a [180I]). Éléments d'idéologie: Idéologie proprement dite. Paris: Courcier.

Destutt de Tracy, A. (I8I7b [18I5]). A treatise on political economy. Georgetown: J. Milligan.

Eiseley, L. (1959). Charles Darwin, Edward Blyth, and the theory of natural selection. Proceedings of the American Philosophical Society, I03(I), 94-I58.

Espósito, R. (2009 [2002]). Immunitas: protección y negación de la vida. Buenos Aires: Amorrortu.

Gale, B. (1972). Darwin and the concept of a struggle for existence: a study in the extrascientific origins of scientific ideas. Isis, 63(3), 32 I-344.

Herbert, S. (I97I). Darwin, Malthus, and selection. Fournal of the History of Biology, 4(I), 209-217.

Kennedy, E. (1979). "Ideology" from Destutt De Tracy to Marx. Fournal of the History of Ideas, 40(3), 353-368.

Lichtheim, G. (1965). The concept of ideology. History and Theory, 4(2), I64-I95.

Lyell, C. (1832). Principles of Geology, being an attempt to explain the former changes of the Earth's surface, by reference to causes now in operation. Vol. 2. London: John Murray.

Malthus, T. (1798). An essay on the principle of population, as it affects the future improvement of society, with remarks on the speculations of $M r$. Godwin, M. Condorcet, and other writers. London: J. Johnson.

Malthus, T. (1826). An essay on the principle of population; a view of its past and present effects on human happiness; with an inquiry into our prospects respecting the future removal or mitigation of the evils which it occasions. London: John Murray.

Metchnikoff, E. (1893). Lectures on the comparative pathology of inflammation. London: Kegan, Trench, Trübner \& Co. 
Metchnikoff, E. (1905). Immunity in infective diseases. Cambridge: Cambridge University Press.

Ostachuk, A. (2015a). La teoría de las dos ciencias: ciencia burguesa y ciencia proletaria. Revista Iberoamericana de Ciencia, Tecnología y Sociedad, io (suppl. I), I9II94.

Ostachuk, A. (2015b). Bogdanov e a teoria das duas ciencias. Sociologia em Rede, 5(5), II4II 8 .

Paley, W. (1802). Natural Theology: or, evidences of the existence and attributes of the deity, collected from the appearances of nature. Philadelphia: John Morgan.

Smith, A. (1791 [1776]). An inquiry into the nature and causes of the wealth of nations. Vol. I. London: Strahan and Cadell.

Tauber, A. (2000). Moving beyond the immune self?. Seminars in Immunology, I2 (3), 24I248.

Tauber, A. (2003). Metchnikoff and the phagocytosis theory. Nature Reviews Molecular Cell Biology, 4(I I), 897-90 .

Todes, D. (1987). Darwin's Malthusian metaphor and Russian evolutionary thought, I859-1917. Isis, 78(4), 537-55 I.

Todes, D. (1989). Darwin without Malthus: the struggle for existence in Russian evolutionary thought. Oxford: Oxford University Press.

Vorzimmer, P. (1969). Darwin, Malthus, and the theory of natural selection. Fournal of the History of Ideas, 30(4), 527-542.

Wells, W. (1818). An account of a female of the white race of mankind, part of whose skin resembles that of a negro; with some observations on the causes of the differences, in colour and form, between the white and negro races of men. In Two essays: one upon single vision with two eyes; the other on dew (pp. 425-439). London: Constable.

Young, R. (1969). Malthus and the evolutionists: the common context of biological and social theory. Past \& Present, 43, I09-I45.

Young, R. (197I). Darwin's metaphor: does nature select?. The Monist, 55(3), 442-503.

Young, R. (197I). Evolutionary biology and ideology: then and now. Science Studies, I(2), I77-206. 